\title{
Pseudokarst and Speleothems in the Chihuido Granite, Province of Mendoza, Argentina
}

\author{
Emilia Y. Aguilera, Silvina Carretero, and Jorge Rabassa
}

\begin{abstract}
The core of the Chihuido Anticline is located precisely at Cerro Chihuido, Malargüe, southern Mendoza province, Argentina. This anticline represents the outcropping pre-Jurassic platform of the margin of the Neuquén Basin, which is composed of three volcano-sedimentary units separated by angular unconformities. The older unit corresponds to the volcano-sedimentary complex named as El Fortín, which concludes with the intrusion of a thick rhyolite-monzogranite dyke. The dyke, together with plutons corresponding to the Gondwana magmatism, is exposed on a paleosurface whose relief has been partly fossilized by much modern pyroclastic rocks. The thickness of the dyke varies from $0.2 \mathrm{~km}$ to almost $1 \mathrm{~km}$. In this landscape, the dyke is the most remarkable topographic and geological characteristic, not only for its huge dimensions but also for its numerous weathering cavities that provide it with a quite peculiar aspect. Typical pseudokarst landforms are represented by tafoni cavities. The nature of pseudokarst is portrayed by selective erosion along joint planes and andesite composition blocks included in the dyke. In the wall of some
\end{abstract}

\footnotetext{
E.Y. Aguilera ( $\square)$

Facultad de Ciencias Naturales y Museo, Universidad Nacional de La Plata (UNLP), Calles 122 y 60, 1900-La Plata, Argentina

DAIS (Dirección de Aplicación de Imágenes Satelitarias), Calle $7 \mathrm{~N}^{\circ} 1267-2^{\circ} \mathrm{P}$, 1900-La Plata, Argentina

e-mail: eaguilera@fcnym.unlp.edu.ar

S. Carretero

Facultad de Ciencias Naturales y Museo, Universidad Nacional de La Plata (UNLP), Calles 122 y 60, La Plata, Argentina

J. Rabassa

Laboratorio de Geomorfología y Cuaternario, CADIC-CONICET, Ushuaia, Tierra del Fuego, Argentina

Universidad Nacional de Tierra del Fuego, Ushuaia, Tierra del Fuego, Argentina e-mail: jrabassa@gmail.com
} 
cavities within the almost vertical dyke, opal speleothems have been formed from silica released by rock weathering. The speleothems were studied by means of optical microscopy, scanning electron microscopy (SEM), and X-ray diffraction. The study of these minor features of the granitic landscape, such as tafoni, and the associated speleothems, the description of their morphology, and the analysis of their composition are the main objectives of this chapter.

Keywords Weathering • Etchplain • Granitic geomorphology • Espelothemes - Geochemistry

\section{Introduction}

The geomorphological study of granite terrains shows a variety of features at the levels of macro- and microscale. Within the latter, tafoni (taffone, singular) are included, also known as weathering cavities. Although these features have been studied on other lithological types, tafoni are common as microlandforms in granitic rocks (Vidal Romaní 1984; Twidale and Vidal Romaní 2005), associated to other features of the granitic landscape. These microlandforms are limited by cavities or void spaces holding a concave profile with varied dimensions. There are classifications of the tafoni types, either in the evolutionary framework of the larger landforms (Vidal Romaní 1984; Vidal Romaní and Twidale 1998; Twidale and Vidal Romaní 2005), in which the cavities are distinguished as equidimensional or heterodimensional, according to their axial relationships, but they also receive various denominations concerning their localization in steep slopes, base of the boulders, etc.

Numerous works developed on the granitic microlandforms are coincident about a genesis in subaerial and/or superficial conditions, as a result of exogenous processes that include many physical and chemical processes. Likewise, these features could be the result of the interaction of exogenous and endogenous processes, such as negative exfoliation and deuterical alteration processes. Since these microlandforms have been identified in different morphogenetic environments, it has been assigned an origin related to process convergence. Finally, Vidal Romaní (1984) linked these microlandforms to rock geotechnical characteristics.

The different minerals that form granite, such as quartz, feldspar, and mica, show a differential behavior in relation to chemical weathering; therefore, a selective alteration of these rocks takes place, controlled by their texture, mineralogical composition, and micro-fissures. Thus, the dissolution acts also through the intracrystalline surfaces (Martini 1984; Urbani 1986; Galán 1988). Recent studies on rocks supposedly considered before as not affected by dissolution have exposed that dissolution is just the chemical aspect of a complex problem, including dissolution rate, duration of the chemical reactions, dynamics of water circulation, and the morphogenetic conditions under certain hydrological aspects (Galán 1991). Pseudokarst, in the sense of Vidal Romaní and Twidale (1998), is considered in this chapter in the context of features developed in granitic or volcanic acid rocks, which show intense similarities with equivalent features found in soluble rocks such as limestone. In Queensland, Australia, several caves have developed in granites, 


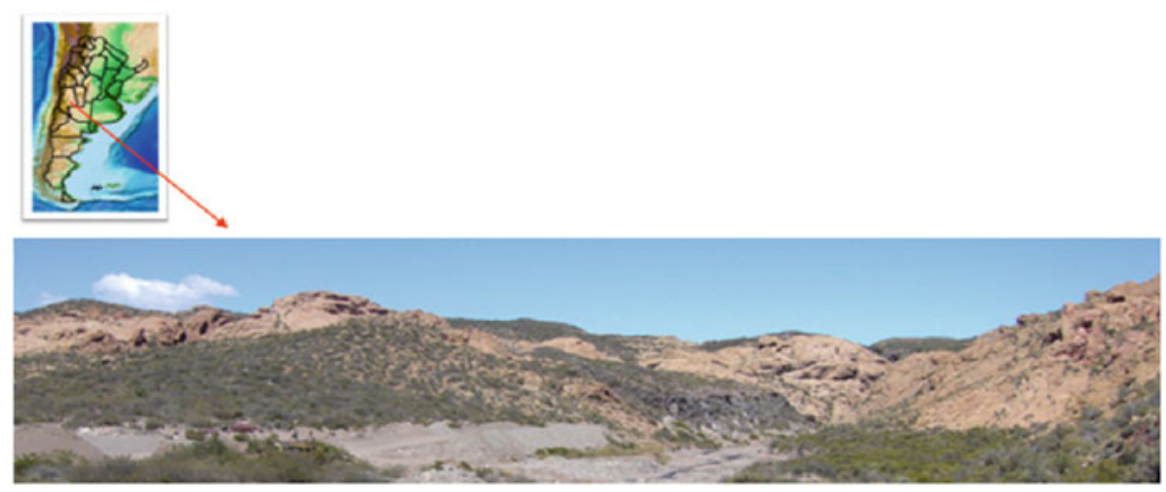

Fig. 1 Localization of the dyke in Cerro Chihuido, south of Malargüe, Province of Mendoza, Argentina, $69^{\circ} 34^{\prime} \mathrm{W}$ and $35^{\circ} 35^{\prime}-35^{\circ} 37 \mathrm{~S}$

some of them such as South Bald Rock Cave and River Cave have opal speleothems of the coral-like type and flowstone on the walls (Webb and Finlayson 1984, 1987). In California, N-NE of San Diego, in the Cahuilla Cave Creek, Finlayson (1985) recognized speleothems of the coral-like type on the walls and flowstone on the floor; both speleothem types are basically of calcite (Webb and Finlayson 1987). Also in Galicia (NW Spain), Vidal Romaní and Vilaplana (1983), Vidal Romaní and Twidale (1998), and Vidal Romaní and Vaqueiro Rodríguez (2007) cited the development of speleothems in granitic rocks. Other authors studied the genesis of speleothems in granitic rocks under a variety of climatic conditions (Fernández Verdía 2000; Sanjurjo 2000). Later, Sanjurjo et al. (2006) studied these dissolution processes in granitic rocks. In Argentina, Cioccale et al. (2008) found siliceous speleothems in open cracks and tafoni walls, in the granitic rocks of the Achala Batholith (province of Córdoba).

\section{Location of the Study Area}

The Chihuido Anticline, located south of Malargüe ( $\left.69^{\circ} 34^{\prime} \mathrm{W} ; 35^{\circ} 35^{\prime}-35^{\circ} 37 \mathrm{~S}\right)$, is close to National Route 40 and has been partially eroded by the Tronquimalal (in the south) and Loncoche (in the north) creeks (Fig. 1).

\section{Geology}

At the core of the Chihuido Anticline (Gerth 1928; Groeber 1947), igneous and sedimentary rocks ranging in age from the Permian to the Middle Jurassic are found. In this period, various cycles of igneous activity took place, following the 
active margin of the Gondwana supercontinent, with ample regional distribution and a very large volume of eruptive rocks, represented by three volcano-sedimentary units, separated by angular unconformities. The older unit corresponds to the El Fortín volcano-sedimentary complex, composed of breccias, lava flows and andesitic domes, and conglomerates and sandstones. The final episode of this unit corresponds to the intrusion of a thick dyke of rhyolite-monzogranite composition, which has been dated on $250 \pm 5 \mathrm{Ma}$, by the $\mathrm{U}-\mathrm{Pb}$ conventional technique. This age allows the correlation of El Fortín Complex with the Choiyoi Group, in the sense of Rolleri and Criado Roque (1970), found in the Cordillera Frontal and the San Rafael Block (Llambías et al. 2005).

The reconstruction of the geological evolution of this region has recorded the existence of angular unconformities in between the Permian and Late TriassicEarly Jurassic eruptive and sedimentary cycles, which are interpreted as tectonic events of varied intensity (Llambías et al. 2005). The sedimentological analyses of these units suggest the existence of an aggressive landscape as a result of the diastrophic movements. The unconformity between the Tronquimalal Group (the overlying unit) and the El Fortín Complex is correlated with the Huarpes diastrophic phase, sometime between 230 and $220 \mathrm{Ma}$ in the Cordillera Frontal, although it could be diachronic. The Huarpes diastrophic phase had a great extension along the active margin of the Gondwana supercontinent. The cited authors remarked that the Triassic outcrops of the Chihuido Anticline correspond to the basin margin, a scenario mainly dominated by the volcanic landscape and not by basin subsidence.

Overlying the Choiyoi Group, continental and marine deposits pertaining to the "Precuyano" units and the Cuyo Group occur, being Early to Middle Jurassic in age. Then the continental and marine deposits of the Lotena Group follow, which culminate with the Oxfordian evaporites of the Auquilco Formation. Several units of Kimmeridgian to Barremian age of the Mendoza Group are found later on, composed of the Tordillo (sandstones), Vaca Muerta (bituminous shales), Chachao (limestones), and Agrio (black shales and limestones) formations. Afterwards, the Rayoso Group is found, of Aptian-Albian age, composed of the Huitrín and Rayoso formations (evaporites, sandstones, and limestones). Fluvial deposits of Late Cretaceous age are overlying, belonging to the Neuquén Group. Finally, Quaternary alluvial and colluvial deposits and basalt and ignimbrite flows complete the sequence.

\section{The Rhyolite-Granite Dyke}

In the Chihuido Anticline region, Backlund (1923) described for the first time a "granite or granitic porphyr," a name later changed to "Chihuido granite and porphyr" (Dessanti 1973). Later on, Llambías et al. (2005) analyzed the unusual thickness and the textural variations of this body, where the porphyritic and micrograined textures are remarkable. Based upon the granular textures, these authors classified the central sector of the dyke as fine-grained monzogranite, where 
the dyke reaches its maximum thickness. This thickness ranges up to almost $1 \mathrm{~km}$ $\mathrm{N}$ of the Tronquimalal creek. These authors observed that in the Loncoche creek, the thickness is of $500 \mathrm{~m}$, occupying the monzogranite approximately $200 \mathrm{~m}$ of the central part, transitionally passing into rhyolites towards the margins of the dyke, where felsitic matrix dominates.

\section{Methodology}

Fieldwork for the reconnaissance and measuring the outcrops and their relief was performed, including identification of the different "in situ" textures of several sectors of the dyke, determination of the fracturing pattern, identification and measurement of the weathering cavities, lithological classification of xenoliths, and search and collection of speleothems. These materials were analyzed by optical microscopy, SEM, and X-ray diffractometry.

\section{Results}

In the field reconnaissance, the dike was found to have $\mathrm{N}$ trend and subvertical attitude. It is accompanied by a parallel system of joints and faults. At a regional scale, this outcrop is part of an exposed paleosurface, but only in the northern sector, where a paleolandscape has been preserved, composed of a fluvial valley buried by modern pyroclastic rocks (the Malargüe Ignimbrite, of Quaternary age; Fig. 2).

At a greater detail, many cavities are observed, most of them tafoni although cavities of the pia/gnamma type, or weathering depressions, are found as well.

Tafoni have sizes ranging from decimeters to meters, and they occur as dispersed in the walls of other granitic landforms. The tafoni host other features that are described here. The development of several shapes and varying morphology has been observed, with dominant equidimensional shapes. In lower zones of the body, their diameters are slightly larger than a few decimeters, whereas in the middle zone, they reach sizes of $60-70 \mathrm{~cm}$, and in the upper part, they grow over $1 \mathrm{~m}$. In the uppermost levels, the shapes of larger size are rocky shelters showing smaller tafoni in their inner portions (Fig. 3). Wall tafoni and basal tafoni have been identified. The larger number of tafoni developed in plunging walls. In very intensively jointed walls, spheroidal weathering features are identified, where rounded nuclei of fresher rock surrounded by thin concentric rock layers are observed (Fig. 4).

With a lower frequency, tafoni developed at the base of isolated boulders limited by orthogonal joint systems have been observed (Fig. 5).

Another group of tafoni of homogenous size, markedly smaller than the previous ones, is localized at the convergence of joint systems and aligned along joint planes (Fig. 6). 

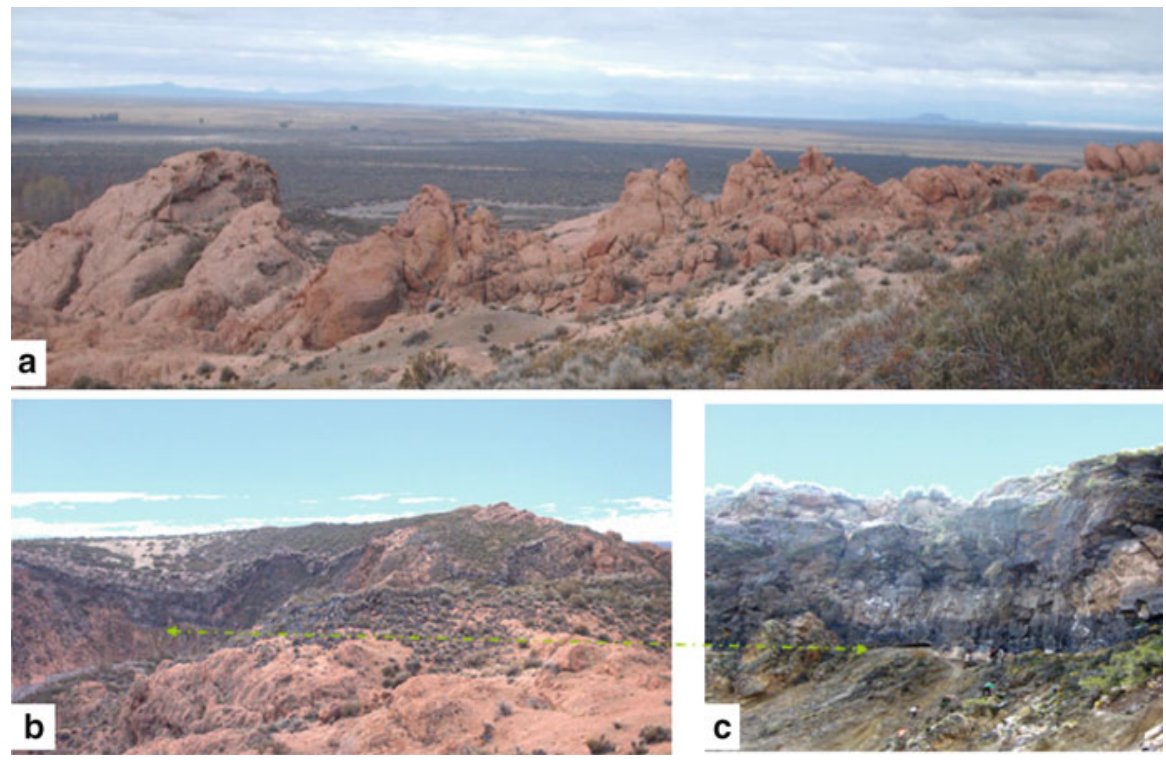

Fig. 2 (a) Panoramic view of the paleosurface. (b) Fluvial valley buried by the Malargüe Ignimbrite (Quaternary). (c) Details of the ignimbrite mantle covering the paleolandscape (the arrow shows the bottom of the valley)
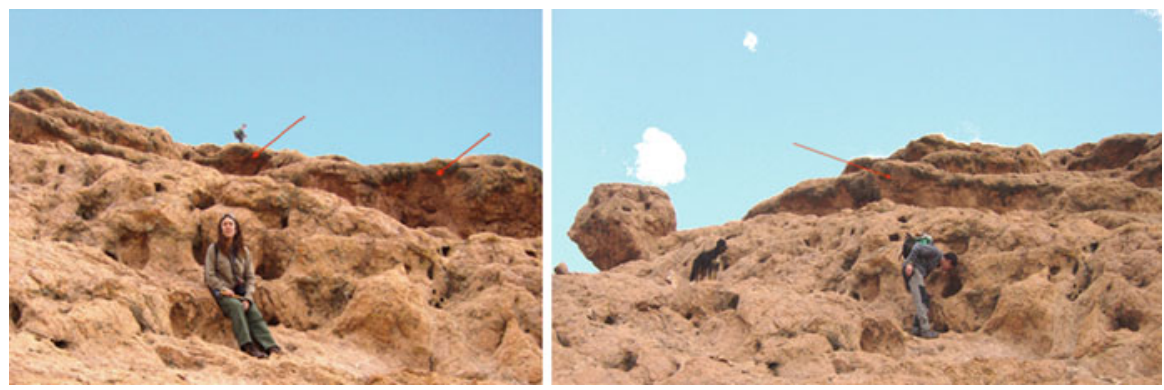

Fig. 3 Summit sectors of the dyke where rock shelters are found showing development of tafoni of a smaller size

On horizontal surfaces on the top of the dyke weathering pits are present, generally associated with tafoni (also known as "pila", "pia", "vasque," or "gnammas"). They are depressions formed by excavation, cavities of variable dimensions that are slightly larger than $1 \mathrm{~m}$ and with depths around $0.60 \mathrm{~m}$. These microlandforms keep rainwater temporarily, and they usually have sediment accumulation in their inner part. According to their morphology, gnammas of flat bottom have been recognized in which no discharge cannel has been observed. Some of these features show wall 

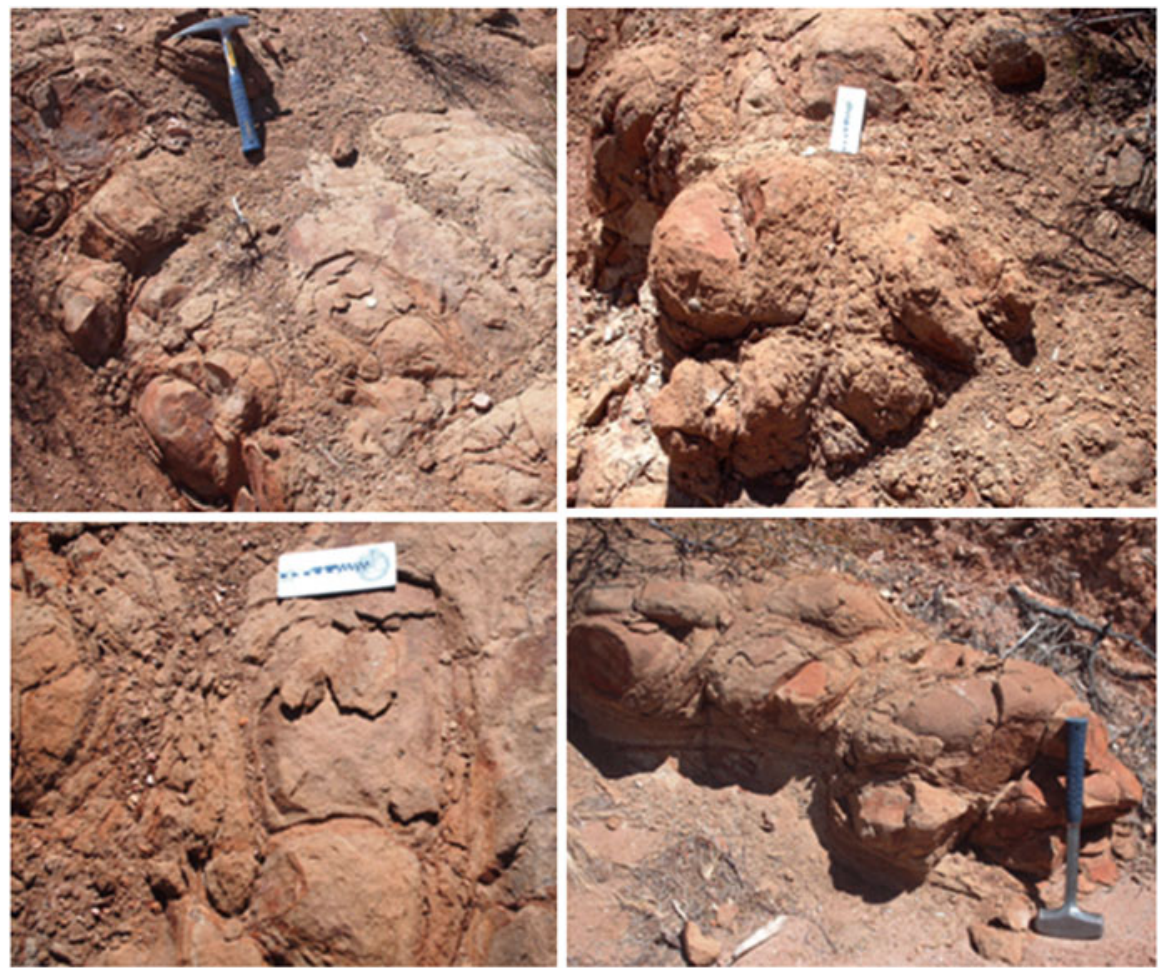

Fig. 4 Features of spheroidal weathering, rounded nuclei of fresher rock surrounded by thin concentric layers
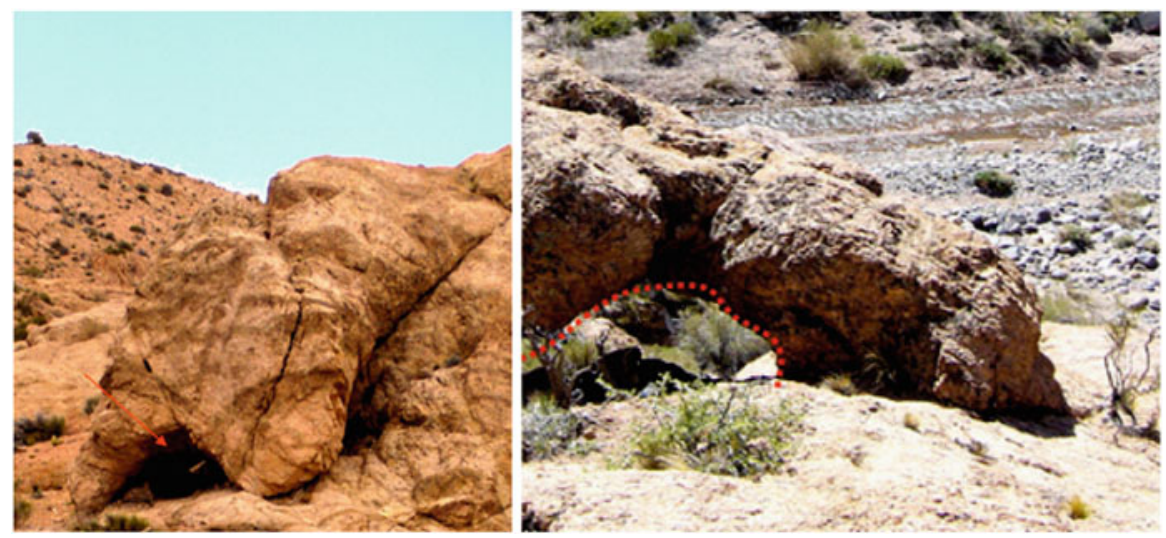

Fig. 5 Tafoni developed at the base of isolated boulders limited by orthogonal joint systems 

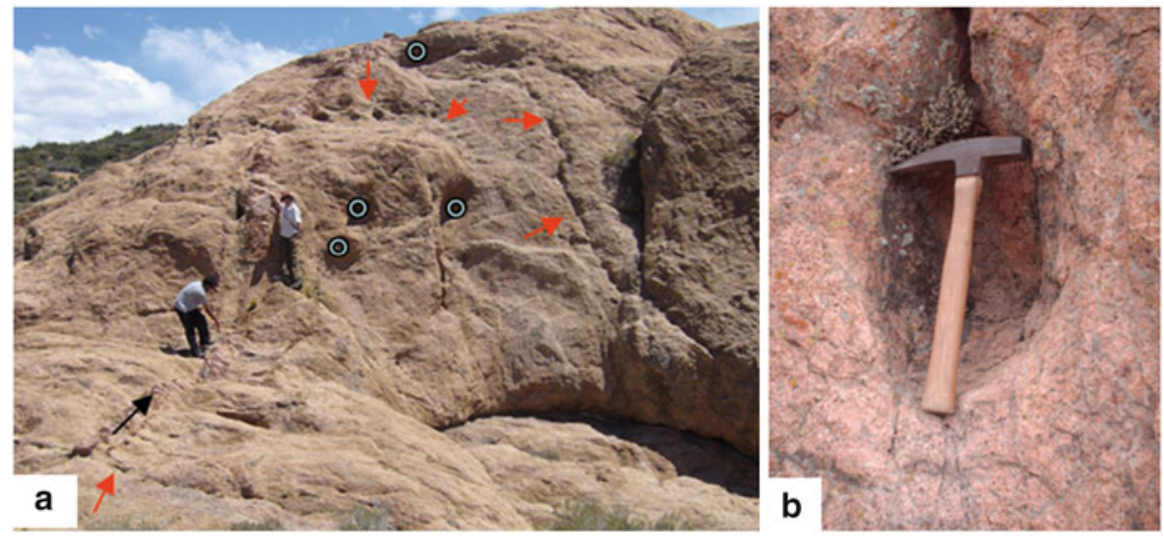

Fig. 6 (a) Alignment of smaller tafoni related to joint systems. Red arrows indicate aligned tafoni along joint planes. Light blue circles depict tafoni of greater size. The black arrow indicates an aplitic dyke. (b) Details of tafoni related to joints

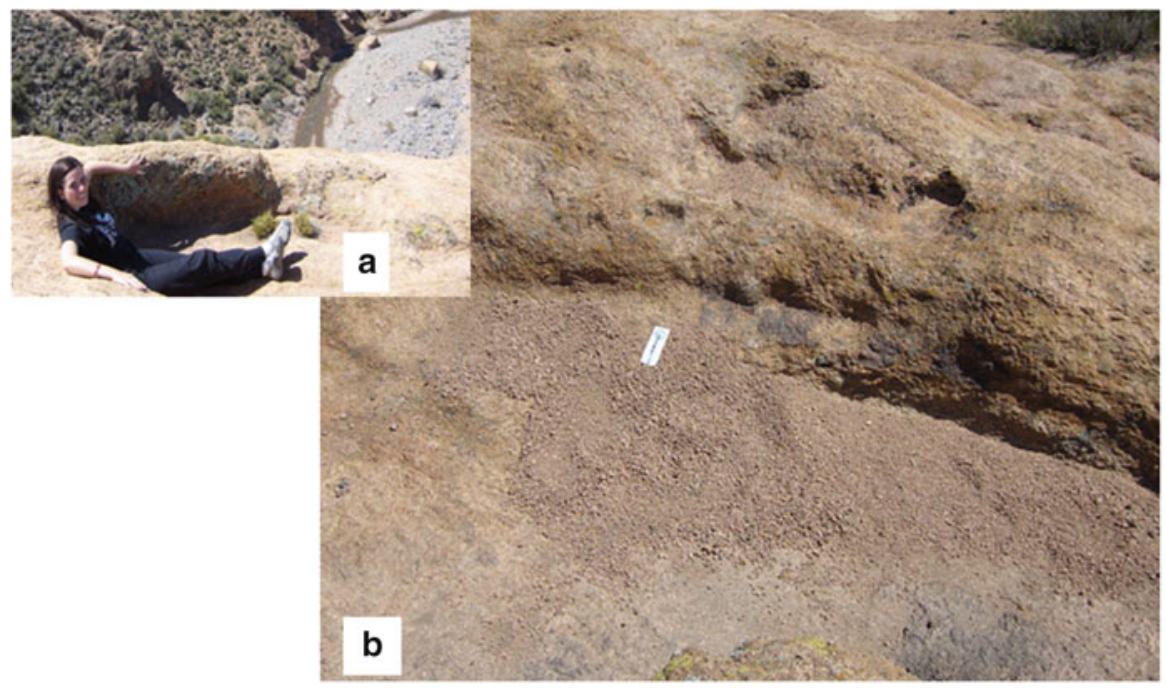

Fig. 7 In the upper topographic levels of the dyke, weathering gnammas developed on horizontal surfaces are identified. (a) Cavities with diameter over $1 \mathrm{~m}$ and a depth of $0.60 \mathrm{~m}$. (b) Details of the granitic debris in the inner part as products of rock degradation

degradation due to a longer exposition to weathering, granitic debris being common in their inner part as a product of rock disintegration (Fig. 7).

In the inner part of some tafoni and open joints, speleothems formed by very thin mineral crusts are found, composed of microcrystalline aggregates of light gray color, milky aspect, and mammillary surface (Fig. 8). At the petrographic microscope, rhythmite layering growth with banded opal is observed. Concerning 


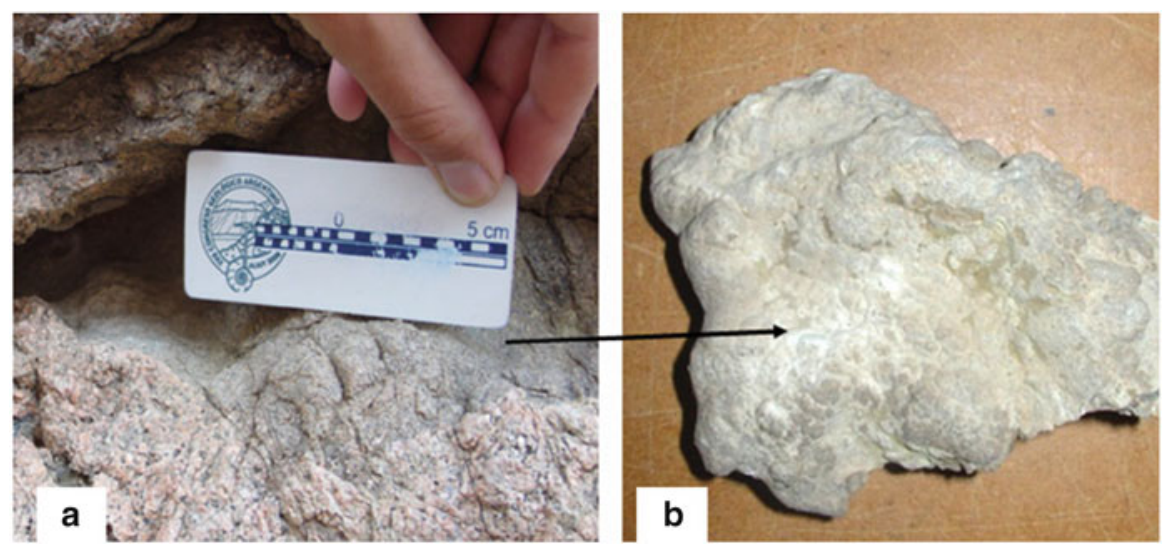

Fig. 8 (a) Speleothem along joints. (b) Macroscopic details of the speleothem composed of lightgrayish, microcrystalline aggregates, of milky aspect and mammillary surface

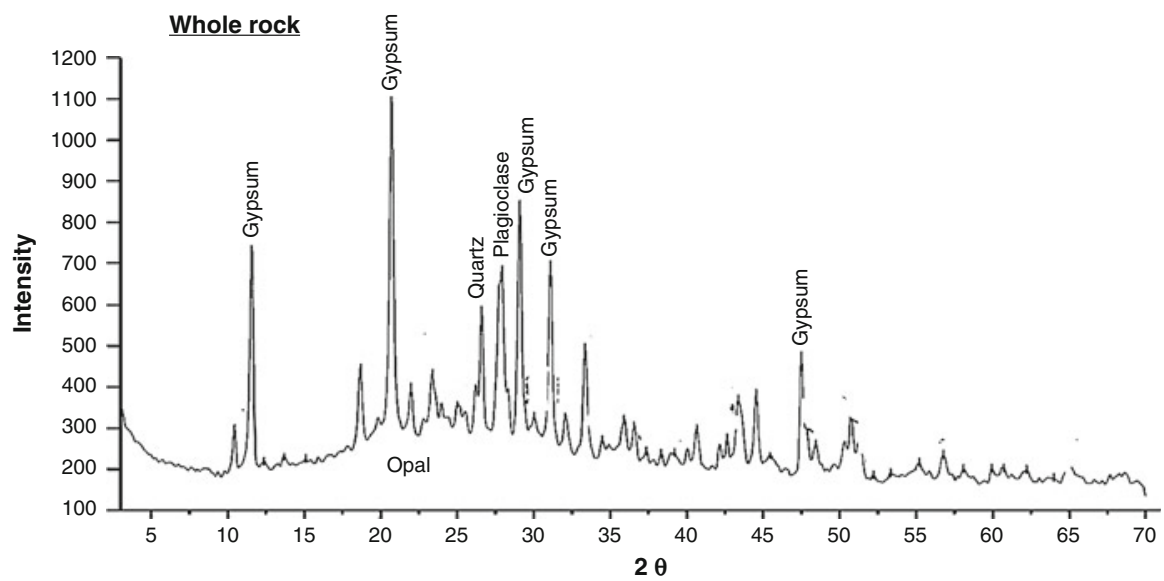

Fig. 9 The XRD records a diffuse peak of extended base with the center located around $26^{\circ}$ ( $2 \theta \sim 3.4 \AA$ ), which is typical of opal A. Peaks corresponding to crystalline silica superposed to opal and other angular values $(2 \theta)$ are found. Other minerals present are feldspars, micas, and gypsum

their mineralogy, analysis by X-ray diffractometry determined that these deposits are basically composed of opal A. The samples show debris components (such as quartz, feldspars, and phyllosilicates) in smaller proportions. The results reveal the presence of amorphous silica, crystalline types of $\mathrm{SiO}_{2}$, and other minerals typical of granitic rocks. The DRX of Fig. 9 shows a diffuse peak of extended base with the center located around $26^{\circ}(2 \theta \sim 3.4 \AA)$ which is typical of opal A. Additionally, 
peaks corresponding to crystalline silica superimposed to the opal in other angular values $(2 \theta)$ have been found. Other minerals present as contaminants are feldspars, mica and gypsum.

With respect to the SEM observations on speleothem samples, results in agreement with the different analyzed sectors were obtained, by contrasting the textures and porosity of the inner and outer surfaces, with approximations of $250 \times$ to $4,000 \times$. Colloform and mammillary forms were observed, typical of solutions that precipitate in cavities. The textures vary according to the precipitation levels. Towards the external zone, rounded (mammillary) shapes are dominant, covered by gypsum crystals of threadlike shape. In the inner part, dish-shaped forms are noticeable, characterized by a continuous opal covering, with concoidal fracture and commonly with superficial perforations as little channels or tubes of diverse inclination (biological activity, perhaps?). These zones occur as interrupted by gypsum levels; these levels show a distinct compaction/porosity from the inner sector to the surface. In the latter case, they behave as thin threads or "whiskers," whereas in the inner zone, they form little rose-type shapes (Fig. 10a-d).

From a chemical point of view, the elementary analyses performed on each sector of the studied samples show that $\mathrm{Si}$ is the major component, accompanied by $\mathrm{Al}$, $\mathrm{Fe}, \mathrm{K}, \mathrm{Na}, \mathrm{Mg}$, Ti, S, and Ca. Si keeps a constant relationship with Al (i.e., 4:1), whereas the relationship with $\mathrm{Fe}$ is $4: 0.5$, and a similar behavior with $\mathrm{Mg}$, both elements of very low mobility. With respect to alkaline elements $\mathrm{Na}$ and $\mathrm{K}$, elements of high mobility, although they are recorded in all samples, their contents are low, as expected. In a few samples, the content of Ti shares comparable values with $\mathrm{K}$. Finally, $\mathrm{S}$ and $\mathrm{Ca}$, abundant in the superficial crust under the mineralogical form of gypsum, are absent in the inner sectors where the opal patina massively covers the speleothem, with the exception of sectors in which thin, rose-type, gypsum layers are interbedded (Figs. 10, 1 and 2).

\section{Conclusions}

The granitic microlandforms analyzed in this chapter are the product of exogenous processes that included numerous physical and chemical processes, forming the so-called granitic pseudokarst. These processes were enhanced by endogenous properties related to the primary structures of the dyke, such as the presence of andesitic xenoliths. These xenoliths would have experimented differential responses to the cited physical and chemical processes, as reflected in the alteration/decomposition of their mineral components. Besides, also in the genesis of these microlandforms, the fissure joint system was involved as well. The pseudokarst process is enhanced by selective erosion along joint planes and andesitic composition xenoliths. Thus, the structural weaknesses of the rocky massif were determined by mineralogy, texture, and joint intersection. 

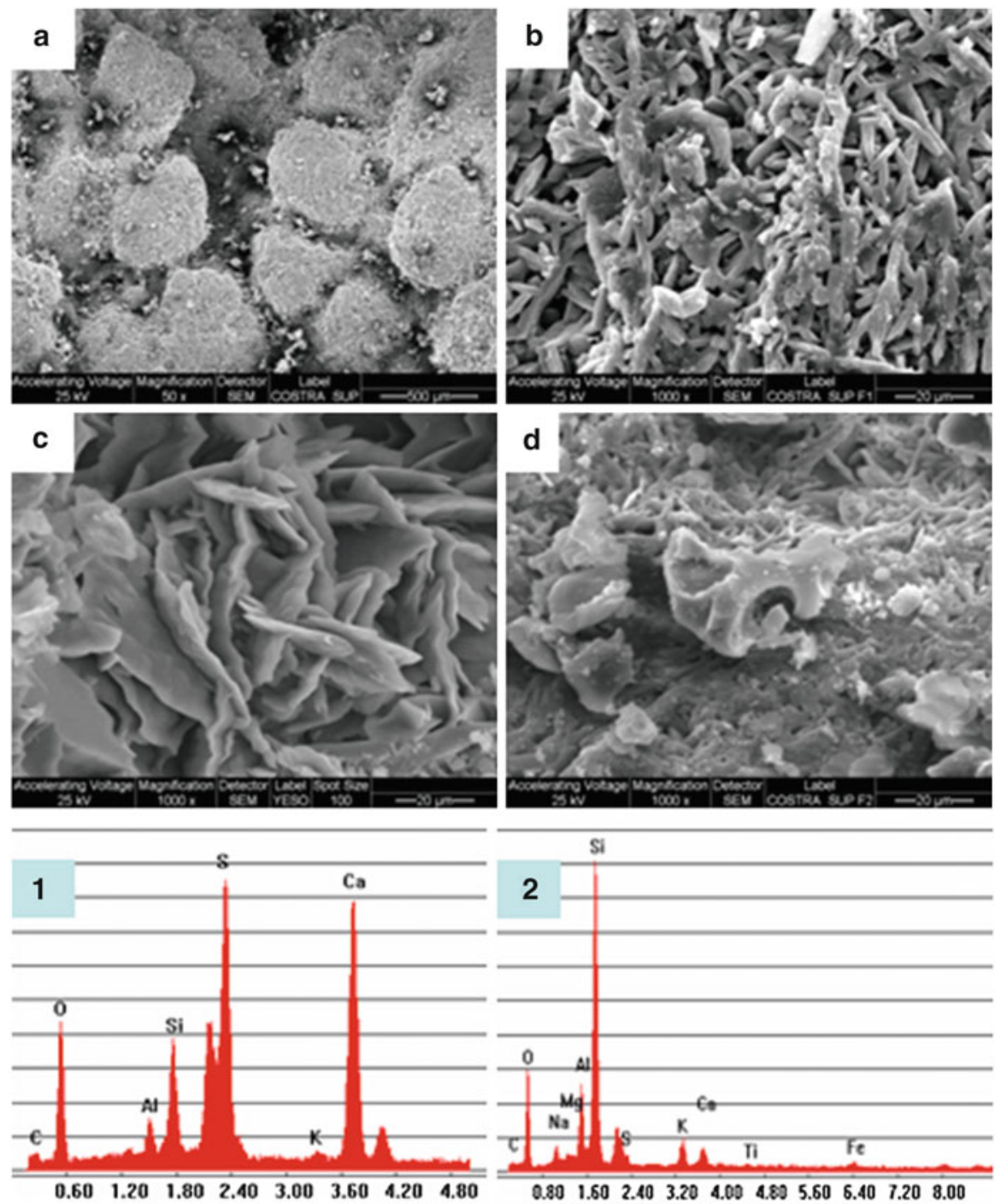

Fig. 10 (a) Superficial view of rounded landforms covered by gypsum crystals. (b) Details of a cavity developed over the rounded shapes. (c) Crystallization of gypsum with tendency to formation of rose-like shaped structures. (d) Inner sector of opal A with tubes/channels and compact gypsum. Semi-quantitative analysis: (1) an external and compact zone of the mammillary texture sample: the high values of S and Ca correspond to the gypsum crystals; (2) of the inner zone of the sample with continuous opal covering, with important presence of Si and, in lower proportion $\mathrm{Al}$ and $\mathrm{Mg}$ due to its lower mobility 
The weathering of granite in the fissure systems was produced by the interaction of water and rock. Rock weathering includes several processes, being the most important the dissolution of the composing elements of the rock, and later, the precipitation of elements and soluble substances, originating speleothems.

With respect to the provenance of the elements recognized in the speleothems, $\mathrm{Si}$, $\mathrm{Al}, \mathrm{Fe}, \mathrm{K}, \mathrm{Na}, \mathrm{Mg}$, and $\mathrm{Ti}$ are considered as autochthonous, that is, direct products of weathering due to dissolution processes of the Chihuido granite, originally composed of orthose, oligoclase, quartz, and biotite. The provenance of Si is clearly linked to feldspars and crystalline quartz, although the intervention of biological activity cannot be ruled out, generating deep changes in $\mathrm{P}$ and even in biogenic opal. The alkaline elements $\mathrm{Na}$ and $\mathrm{K}$ are liberated from the decomposition of plagioclase, either oligoclase [ $\left.(\mathrm{NaCa}) \mathrm{AlSi}_{3} \mathrm{O}_{8}\right]$ or $\mathrm{K}$ in orthose $\left(\mathrm{KAlSi}_{3} \mathrm{O}_{8}\right)$; similar origin is assigned to $\mathrm{Al}$. Meanwhile, the alteration of biotite $\left\{\mathrm{K}_{2}\left(\mathrm{Mg}, \mathrm{Fe}^{2+}\right)_{6-4}\left(\mathrm{Fe}^{3+}, \mathrm{Al}\right.\right.$, $\left.\mathrm{Ti}_{0-2}\left[\mathrm{Si}_{6-5} \mathrm{Al}_{2-3} \mathrm{O}_{20}\right](\mathrm{OH}, \mathrm{F})_{4}\right\}$ is responsible for the concentration of $\mathrm{Fe}, \mathrm{Mg}, \mathrm{Ti}$, $\mathrm{K}$, and $\mathrm{Al}$.

In relation to $\mathrm{S}$ and $\mathrm{Ca}$, these elements are considered as foreign to granite, that is, allochtonous. Their provenance would be related to the Mesozoic formational units of the Neuquén Basin, characterized by important deposits of marine limestone of the La Manga Formation (Lotena Group), which culminates with Oxfordian evaporites (gypsum) of the Auquilco Formation, and also limestone belonging to the Chachao and Agrio formations (black shale and limestone) of the Mendoza Group (Kimmeridgian to Barremian). Likewise, extensive evaporate sheets with dominant gypsum and Ca-carbonate of the Rayoso Group, Aptian-Albian in age, composed of the Huitrín and Rayoso formations could be the source of these elements.

One aspect that should be taken into consideration is the genesis of the speleothems in the interior of the weathering cavities is the supply of organic matter and microorganisms. The opal deposits have probably been originated to a certain point by organic chemical reactions, but these studies have not proven it yet. The investigation should continue to solve some questions as the participation of microorganisms in the development of opal and other minerals.

Finally, future studies will have to inform and clarify about the age and environmental conditions of the speleothems and whether they have been formed recently or if they are relicts of much more humid climates of a very distant past.

\section{References}

Backlund H (1923) Der magmatische anteil der Cordillera von süd Mendoza. Meddeladen fran Abo Akademis Geologisk-Mineralogiska Institut 3:1-298, Abo

Cioccale MA, Pasquini AI, Depetris PJ (2008) Hallazgo de espeleotemas silíceas en rocas graníticas del batolito de Achala, Sierras Pampeanas de Córdoba. Revista de la Asociación Geológica Argentina 63(3):417-420

Dessanti RN (1973) Descripción geológica de la hoja 29b, Bardas Blancas (Provincia de Mendoza). Servicio Nacional Minero Geológico, Boletín 139:1-70, Buenos Aires 
Fernández Verdía MA (2000) Estudio de la génesis de espeleotemas en granitoides en climas áridos (Salt River, Kellerberrin, Western Australia). Unpublished graduation thesis, Universidade da Coruña, A Coruña, Spain, $81 \mathrm{pp}$

Finlayson BL (1985) The formation of caves in granite. In: Sweeting MM, Paterson K (eds) New directions in karst. Geobooks, Norwich

Galán C (1988) Cavernas y formas de superficie en rocas precámbricas del Grupo Roraima (Guayana Venezolana). Bol SVE 23:1-12

Galán C (1991) Disolución y génesis del Karst en rocas carbonáticas y rocas silíceas: un estudio comparado. Munibe (CiencNat), SCAranzadi 43:43-72

Gerth E (1928) La estructura geológica de la Cordillera Argentina entre el Río Grande y el Río Diamante. Academia Nacional de Ciencias, Actas 10(2):125-172, Córdoba

Groeber P (1947) Observaciones geológicas a lo largo del Meridiano 70. Hojas Barda Blanca y Los Molles. Revista de la Asociación Geológica Argentina 2(4):409-433

Llambías EJ, Sato AM, Basei MAS (2005) El basamento pre-jurásico medio en el anticlinal Chihuido Malargüe: evolución magmática y tectónica. Revista de la Asociación Geológica Argentina 60(3):567-578

Martini J (1984) Rate of quartz dissolution and weathering of quartzite. Bull S Afr Speleol Assoc 25:7-10

Rolleri EO, Criado Roque P (1970) Geología de la provincia de Mendoza. IV Jornadas Geológicas Argentinas (Mendoza), Actas 2:1-60, Buenos Aires

Sanjurjo J (2000) Estudio comparado de la génesis de espeleotemas sílíceos en granitoides en climas semiáridos y templado-húmedos. Unpublished graduation thesis, Universidade da Coruña, A Coruña, Spain, 72 pp

Sanjurjo J, Fernández Mosquera D, Vidal Romaní JR (2006) Procesos de disolución en ambientes seudocársticos graníticos. Actas de la IX Reunión Nacional de Geomorfología, Santiago de Compostela, pp 773-784, ISBN 84-9750-641-3

Twidale CR, Vidal Romaní JR (2005) Landforms and geology of granite terrains. Balkema, London, $351 \mathrm{pp}$

Urbani F (1986) Una revisión sobre las cavidades y demás formas relacionadas desarrolladas en las rocas cuarcíferas precámbricas del Grupo Roraima, Venezuela. Interciencia 11(6):298-300

Vidal Romaní JR (1984) Microformas graníticas tipo Tafoni (Cachola) y Gnamma (Pia). Un micromodelado sin relación con el clima o la estacionalidad. Caderno Laboratorio Xeolóxico de Laxe 7:273-277

Vidal Romaní JR, Twidale CR (1998) Formas y paisajes graníticos. La Coruña. Universidad da Coruña, $411 \mathrm{pp}$

Vidal Romaní JR, Vaqueiro Rodríguez M (2007) Types of granite cavities and associated speleothems: genesis and evolution. Nat Conserv 63:41-46

Vidal Romaní JR, Vilaplana JM (1983) Datos preliminares para el estudio de espeleotemas en cavidades graníticas. Cadernos Laboratorio Xeolóxico de Laxe 7:305-324

Webb JA, Finlayson BL (1984) Allophane and opal speleothems from granite caves in south-east Queensland. Aust J Earth Sci 31:341-349

Webb JA, Finlayson BL (1987) Incorporation of $\mathrm{Al}, \mathrm{Mg}$, and water in opal-A: evidence from speleothems. Am Mineral 72:1204-1210 